\title{
Greening retail
}

Received (in revised form): 29 August 2007

\section{Sue Robinson}

is a freelance writer who specialises in feature articles about property, technology and future directions. Her career, like those of many other baby boomers, has included an eclectic mix of professions ranging from musician to business trouble shooter and including a brief spell as a champion poker player. Originally from the UK, she has lived in Australia for most of her life and is now semi-retired and working from her home near one of three coastal lakes on the NSW Central Coast.

\section{Abstract}

Much has been made of sustainable design in commercial office buildings, but where are our retail centres in this rush to 'green' our cities?

\section{Keywords:}

Australia, retail, shopping centres, sustainability, green, energy

First published by Property Australia magazine, September 2007

Journal of Retail and Leisure Property (2007) 6, 287-290. doi:10.1057/palgrave.rlp.5100070

Romilly Madew of the Green Building Council of Australia (GBCA) says the new Green Star - Shopping Centre Design rating tool will help assess the environmental attributes of the base building component of new shopping centres, as well as additions and major refurbishments for existing centres. She also hopes it will influence individual retailers' choice of location.

The GBCA got its first enquiries from commercial offices, but retail soon followed. There was special interest from major owners such as Mirvac, Westfield, AMP Capital, Stockland, ING Real Estate and Lend Lease, which formed the technical working group and joined the Victorian Government's Sustainability Victoria in sponsoring the tool's development.

But although the Shopping Centre tool was started in 2005, it is still in the pilot stage. It has taken much longer to develop than other ratings tools. Why?

First, there is retail's mix of users. Shopping centres have large tenancies in the form of anchor stores (like supermarkets and department stores), as well as, in Madew's words, 'hundreds of little tenants'. If these tenants do not cooperate with environmentally sustainable centre operation, they can undo a lot of good design and planning.

Shopping centres also have to accommodate hugely varying needs.

Sue Robinson 5 Wombat Street Berkeley Vale NSW 2261 Australia

Tel: +61 (o) 243894779 E-mail: surob@aapt.net.au
For example, hairdressers use a great deal of water and eateries are heavy consumers of power.

Further complicating the issue is community use of shopping centres. Customers often use the centres as refuges in intemperate weather. So how do you assess the community benefit when people share a shopping 
centre's air-conditioning instead of turning on their own? User numbers also change dramatically with the seasons.

Shopping centres also take up a much larger land area than office buildings (making them more expensive to retrofit) and the majority are in the suburbs, away from public transport hubs, yet sustaining a much larger traffic throughput than other commercial premises. Even when centres are close to public transport, many shoppers insist on using cars to transport their shopping.

Herbert, Greer \& Rundle's Robert Wilcher chairs the Property Council's NSW division sustainable development committee and cites transport as a major hurdle for greening the retail environment. 'Shopping centres are designed to be accessed by cars', he says. With a traditional office rating tool, this obsession with cars would seriously hamper ratings.

The office ratings tool also considers access to daylight as important, but many centres use skylights, instead of windows to provide light. These might save on light bulbs but can also play havoc with airconditioning efficiency. Longer opening hours for shopping centres, as opposed traditional office hours, also create more energy and water use.

Madew also reports that the office rating tool included the Australian Building Greenhouse Rating (ABGR) as a mandatory component, but there was no ABGR energy calculator for shopping centres so the working group had to develop its own, using sponsors' centres as case studies.

So quantifying 'green' in retail is complicated. The major players involved in developing the tool were highly motivated, but even they had a patchy understanding of the subject. Madew reports that the GBCA had to spend time educating them and gaining their commitment. 'We had to bring them on the journey with us and, for the shopping centre guys it took time - more time than for the other tools'.

She says the Australian situation is very different from overseas, where demand for sustainable centres came first from the major retailers. In the UK, for example, Marks \& Spencer has launched a five-year green strategy to combat climate change.

Norman Disney \& Young's Stuart Fowler agrees that Australian retail is a little behind the pack. 'I think in a lot of ways we're learning the ropes', he says. 'For example, White City in Central London, a Westfield development, estimated that 60 percent of all the shoppers will get there on public transport'. This, he adds ruefully, is unlikely to be matched in Australia.

Dr Caroline Noller, GPT's head of corporate responsibility, notes that 'the consumer awareness of the US and the EU/UK has increased activities of large retailers like Sainsbury, Tesco, Wal-mart which we are now seeing here with Coles and Woolworths. This is good'. She says both our supermarket chains have sophisticated procurement processes, which complicate issues, so they are running trials for different green initiatives in their stand-alone community centres. 'I think that they are moving impressively quickly', she says.

Australia has local issues too - like materials. GPT seeks sustainable materials, such as sustainable timber, for its developments. 
'We're constrained at this point', says Noller. 'We feel we don't have enough materials suppliers offering what we consider to be zero impact materials'. There are also problems finding recycled aluminium (aluminium has a huge embodied $\mathrm{CO}_{2}$ component which is significantly reduced when recycled). In fact, says Noller, recycled product mostly has to be imported, which can be counter-productive in terms of reducing the carbon footprint.

All these issues 'restrict our ability to move much beyond a 20 percent impact reduction overall', says Noller.

Greening retail will not work unless the customers are brought into the picture. According to Fowler, the ESD movement in commercial property gained impetus from tenants demanding change. In shopping centres, the public vote with their feet, he says, and currently neither customers nor tenants will shun a centre just because it isn't green.

\section{WHAT CAN BE DONE?}

Water and energy use are obvious areas for improvement, but other issues should also be on the radar. Noller says everything has a different impact, which is worth being aware of. 'Materials [are] around 40 percent of impact, transport [is] around 10-15 percent, energy around 20 percent. Water [is] hard to calculate at present. There are many smaller focus points through the operational chain such as cleaning products, cleaning practices and refrigerants, which also need attention but do not [have] as great an impact'.

Wilcher approaches the issue methodically. First, audit the situation: find out what their resource consumption is, look at how water is metered, check for leaky pipes, endlessly flushing toilets and types of lighting. In other words, fix the obvious problems before tackling the harder issues of thermal quality and solar orientation. Coles, for example, is adjusting internal layout to reduce energy consumption — such as in the chilled food areas.

Fowler suggests following the average householder's example. 'The recent drought has certainly focused everyone's attention on water and the need to harvest rainwater. Shopping centres have huge areas of roof', he says, which provides plenty of potential for rainwater capture. They could also use more efficient light fittings and control systems and cut back on the air-conditioning. Recycling is another suggestion, and 'at a higher level, all centres can encourage public transport to the centres'.

But Noller says the most gains are achieved at the planning stage before a centre is built. 'We now know that new build or large extensions can achieve double the footprint/impact reduction as retrofit to existing centres', she says. If you do retrofit, Fowler says, the biggest gains 'are probably to be made in the malls', which have just the one owner.

But sustainability technology is bounding ahead. Noller says with the four Quad buildings at Homebush for example, each was more environmentally efficient than the one completed before. Even so, GPT has had to retrofit them within five years of completion to add green features not available during construction. 
Government is slowly beginning to add incentives to the mix. Noller cites the Sydney Water DIY programme where flow restrictors were provided for taps. 'This means ... every retailer now has them and we have seen a 10-15 percent reduction of water consumption as a result'. There is also an ecological footprint calculator for retailers, developed with EPA Victoria.

So it looks like retail is on the road to sustainability. Madew says government initiatives will help. The Federal Government is forming a policy to audit high-energy users and shopping centres will be taken up in that. 'But', says Madew, 'I don't think it will be as fast as office'. 